\title{
Thoughts on the Construction of Network Ideological and Political Education Matrix in Local Colleges and Universities
}

\author{
Qiqi Wei ${ }^{1, *}$ \\ ${ }^{1}$ Guangxi University of Science and Technology, Liuzhou, Guangxi Zhuang Autonomous Region, China \\ *Corresponding author. Email:85638562@qq.com
}

\begin{abstract}
Based on a local university in central Guangxi, through the analysis of the problems existing in the network ideological and political education and the analysis of the current situation, this paper finds out the significance and methods of carrying out the network ideological and political work in colleges and universities, and puts forward targeted opinions and suggestions. Urge local colleges and universities to make full use of the network and its advantages to carry out ideological and political education under the situation actively.
\end{abstract}

Keywords: Network ideological, Political education, Matrix local, Colleges and universities.

\section{INTRODUCTION}

The Internet has a great impact on college students' daily study, work-life and even physical and mental health, social practice and so on. With all-round development of the new media client not only brings a subversive revolution to the traditional ideological and political education but also brings severe challenges to the network ideological and political education. With the help of the Internet for ideological dissemination, ideological indoctrination, socialist spiritual civilization construction, professional knowledge and skills learning, all kinds of competitions, etc., college students browse news at home and abroad through the Internet, learn the knowledge of network courses, and understand the information of various industries in the world. The Internet has become the main position and channel of learning and education. How do local colleges and universities make full use of network means to innovate ideological and political education, cultivate and practice socialist core values among college students, grasp the initiative and discourse power of network public opinion, guard the propaganda and ideological position, and construct the matrix of network ideological and political education? it has become an urgent problem for colleges and universities to solve.

\section{THE EXISTING PROBLEMS IN THE NETWORK IDEOLOGICAL AND POLITICAL EDUCATION IN COLLEGES AND UNIVERSITIES}

\subsection{The Construction of the Position of Network Ideological and Political Education is not Solid, and It does not Seize the Highland.}

It is mainly manifested in that the content is not vivid enough, and the form is not diversified enough. According to the investigation, there are not many theme education websites and red websites set up by colleges and universities in Guangxi. Even if there are, the contents are relatively boring and interactive, and most of them are directly reprinted or quoted. Most of the typical cases are mainly based on the speeches of leading cadres, which is not easy to arouse the attention of college students and arouse their interest in learning. The practice of most colleges and universities is in the form of special projects, by setting up a small icon with a quick entrance on the website, the topic content is different in each time period, and the later study will soon cover the previous one. The learning of network ideological and theoretical courses is mainly in the form of online open courses, which is relatively single, which is not in line with the reality of college students' study and life, and lacks interaction. 


\subsection{The Network Information is Intermingled with the Good and the Bad, and the Values of College Students are Easily Affected.}

The network is an important platform for college students to obtain knowledge and information, but the network is full of all kinds of information, which needs college students to learn to judge what is true and reliable information and what is false information. The ideological system of college students has not yet been finalized, lack of stability, and is extremely vulnerable to the adverse effects of network information. College is a critical period for college students to form ideological and political values. How to identify and judge the information obtained, as well as the complexity of network information, has brought a huge test to the network ideological and political education in colleges and universities.

\subsection{There are Limitations in the Mode of Network Ideological and Political Education.}

According to the survey, the current ideological and political education received by college students mainly comes from the theoretical courses of ideological and political education, and the practical and educational activities they participate in are still mainly from offline, and the source of the activities is still based on the top-down requirements of the party and government departments.Lack of attraction to college students, the effect is not good. At present, the network ideological and political education carried out by local colleges and universities is mainly based on the website (web version) education model, which is lack of dynamic update, lack of close connection between cases and real life, and lack of effective use of Weibo, Wechat and so on. College students' recognition of the current mode of network ideological and political education in colleges and universities is low.

\section{AN ANALYSIS OF THE CAUSES OF THE PROBLEMS IN NETWORK IDEOLOGICAL AND POLITICAL EDUCATION IN COLLEGES AND UNIVERSITIES}

\subsection{The Function of Network Ideological and Political Education in Colleges and Universities has not been Brought into Full Play, and the Construction Lags Behind.}

The network ideological and political education in local colleges and universities has too much grasp of the single point and insufficient use of the support point in the selection of network carriers, taking into account one at the expense of the other, and does not consider the space for cross-selection and utilization of ideological and political education websites, QQ, Wechat and Weibo. The ideological and political education websites of local colleges and universities are either unreasonable, the home page is not beautiful, or the information and news lags behind, the content is boring, and is not liked by the students. On the other hand, local colleges and universities in the use of QQ, Wechat, Weibo and other interactive is not strong, the function has not been brought into full play, has not formed a comprehensive offensive, the advantages of network ideological and political education has not been fully brought into play, and the educational function has not been fully realized.

\subsection{Due to the Lack of Effective Supervision and Active Guidance of Network Public Opinion, There is Still a Vacuum.}

Contact can trigger a series of events, and in the era of "everyone is self-media", it takes less than a few minutes to apply for an account and no technical editing to upload real-time events to the web through the mobile phone. Because of the "sense of existence" and personal behavior habits, some college students enjoy it and upload "blockbuster" and "burning" content. Local colleges and universities all attach great importance to the supervision of network public opinion, but due to limited personnel and energy, lack of technical means and management channels, some negative information is spread on the network carrier, without timely targeted guidance, and some college students with poor discrimination ability, their outlook on life and values will be impacted and affected..

\subsection{The Ecological System of Network Ideological and Political Education has not been Built, and a Joint Force Has not been Formed.}

Due to the conditions and direction of running a school, the current network of ideological and political education in local colleges and universities has not yet formed a full ecology, and each department does things in its own way. The main reason for this problem is that local colleges and universities have not formed a joint force on network ideological and political education, including the relative simplicity of the team, the lack of independent research on related theories, the disintegration of network platforms and carriers, and uneven content quality. This is extremely disadvantageous to the network ideological and political education in local colleges and universities. Do not realize the importance of forming a joint force, do not form a matrix and gridding; it is still difficult to carry out network ideological and political education for college students. 


\section{THOUGHTS AND SUGGESTIONS ON NETWORK IDEOLOGICAL EDUCATION IN LOCAL COLLEGES AND UNIVERSITIES}

\subsection{Promote the Construction of Positions and Expand the Influence of Network Culture in Colleges and Universities.}

Local colleges and universities should vigorously promote the construction of the main position of network ideological and political education, and basically form an ecological system of network positions, such as comprehensive portals, thematic education websites, professional academic websites and "two micro and one end". We will effectively expand the coverage of network culture education and social services. Most colleges and universities in Guangxi have joined the YiBan to actively explore the network interactive community construction model to achieve resource sharing, work cooperation and information exchange. Guangxi University of Science and Technology adheres to "people-oriented", highlights the principles of user orientation and interaction, and promotes the integration and development of emerging media and campus traditional media. In recent years, the purchase of servers, the revision of the school website, the use of offline popular design mode, the construction of the secondary college website is all under the management of the campus network center, and the off-campus domain name website is closed and exited. Strengthen supervision and standardized management of Weibo and Wechat of secondary colleges. The radio stations, school journals, school newspapers, student media centers, press stations and other organizations will be integrated and merged, which will be uniformly managed by the propaganda Department of the Party Committee of the school. Achieve the mobilization of teachers and students, jointly promote the integration of the media, form a strong joint force of propaganda; hold the propaganda position to ensure ideological security; tell a good story of HKUST, jointly shape the development of a new image; serve the growth of young people, and enhance service skills.

\subsection{Integrate Resources and Strengthen the Construction of College Students' Online Propaganda and Education Organizations or Associations.}

Guangxi University of Science and Technology has set up a campus-level all-media center for college students, which is formed by the integration of the former college student media center, youth new media center, YiBan workstation and so on. The establishment of the all-Media Center for College students of Guangxi University of Science and Technology is not only a practical action to implement the spirit of General Secretary Xi Jinping's important speech at the national propaganda and ideological work conference, but also the 12th collective study held by the political Bureau of the CPC Central Committee in the people's Daily on January 25 this year on the era of all-media and the development of media integration. General Secretary Xi Jinping put forward specific measures to "accelerate the development of media integration and build a media-wide communication pattern". The all-Media Center for College students of Guangxi University of Science and Technology is a student mass organization directly managed by the propaganda Department of the Party Committee under the leadership of the Party Committee of Guangxi University of Science and Technology, which receives the specific guidance of the Student work Department of the Party Committee and the Youth League Committee of the school in related business.

\subsection{Strengthen the Supply and Service to Enhance the Attractiveness of Network Culture in Colleges and Universities.}

Colleges and universities effectively integrate high-quality educational and cultural resources, actively carry out lively ideological and political education activities, form a joint force of online and offline ideological and political education, improve the level of service, and strengthen the ability to deal with risks and guard against risks. Enhance the pertinence and effectiveness of network ideological and political education in local colleges and universities, and serve the all-round development and healthy growth of students. Guangxi University of Science and Technology actively participated in the excellent national projects and team selection activities of college students' social practice, the national college student photography micro-film competition, the national campus sound network competition, etc., and held the most beautiful University of Science and Technology. The selection of College students' person of the year, looking for the good Young people of GXUST and singing the good Voice of GXUST. Tell the story of the University of Science and Technology "and other activities, set models and examples, through the school, college two-level platform push, strengthen the construction of online ideological and cultural positions, and enhance the attractiveness of network culture. At the same time, Guangxi University of Science and Technology actively promotes network management laws and regulations, improves the guarantee mechanism, purifies the network environment, and builds a positive, healthy and sunny network ideological and cultural position and network management system. 


\subsection{Strengthen Internet Thinking and Organically Combine Online and Offline Ideological and Political Education.}

It is necessary to study and grasp the laws of modern news communication and the development of emerging media, strengthen Internet thinking and the concept of integrated development, and promote the effective integration of various media resources and factors of production. We will promote the sharing and integration of information content, technology applications, platform terminals, and talent teams. Guangxi University of Science and Technology closely follows the new Internet technology, through online and offline linkage, gather high-quality education and teaching resources to serve students' learning needs, integrate high-quality literary and cultural resources to serve students' spiritual needs, broaden and enrich employment and entrepreneurial resources to serve students' development needs, provide daily convenience resources to serve students' life needs, and enhance the affinity and influence of college students' ideological and political education. In view of the fact that college students' favorite form of strengthening ideological and political education is the characteristics of social practice and case analysis, Guangxi University of Science and Technology combines network ideological and political education with practical social activities. in the summer social practice, we will actively carry out "party members to the grass-roots level", "professional cultural service team construction", "looking for veteran party members" and "spreading red education." Through activities such as "sowing Red Gene", and through online voting and evaluation, college students are not only affected by the excellent deeds in the dissemination of online ideological and political education but also through a variety of online and offline activities to implement and implement educational requirements.

\subsection{Strengthen the Construction of Network Carriers and Enrich the Content and Form of Network Ideological and Political Education.}

In his important speech at the National Network Security and Informatization work Conference, Xi Jinping stressed that we should carry out in-depth ideal and belief education, deepen the propaganda and education of socialism with Chinese characteristics and Chinese Dream in the new era, and actively cultivate and practice the core values of socialism. we should promote the innovation of online propaganda ideas, contents, forms, methods and means, grasp the effectiveness of time, build a concentric circle off the network, and better forge social consensus. Consolidate the common ideological basis for the unity and struggle of the whole party and the people of the whole country. Widely carry out online and offline practical activities with a distinct theme, healthy content and lively form, so as to enhance college students' understanding of real and virtual society. Guangxi University of Science and Technology strengthens the construction of network carriers. First, it publishes information and news related to ideological and political education through the campus network with official authority, so as to facilitate discussions among teachers, students and all walks of life. All kinds of news and information related to ideological and political education are updated regularly, providing protection for college students' ideological and political education and providing authoritative sources of information for the propaganda of new media platforms. The second is to build the YiBan into a comprehensive network community suitable for the ideological and political education of teachers and students in the whole school. The development of the basic functions of YiBan ensures the interest and practicality of the ideological and political education in $\mathrm{t}$ YiBan college, is conducive to the continuous promotion of the platform, and creates a win-win situation between ideological and political education and the Internet. Third, focus on the Wechat platform to become a popular information contact terminal, large screen live broadcast, external network link activities, real-time news push, etc., set up WeChat's unique network ideological and political propaganda system, which has played a positive and positive role in the "three values education" of teachers and students, and well supplemented and extended the development of offline ideological and political education. Fourth, based on the diversity and interest of Weibo functions and a wide audience, it focuses on developing a "Weibo big screen" function that is conducive to network ideological and political education activities, and holds several issues of online ideological and political Weibo topic discussion. Trigger extensive discussion and forwarding, moisturizing all things quietly convey the sincerity and positive energy of network ideological and political education. Effective combination of Weibo, Wechat and other carriers, so as to better promote ideological and political education; fifth, on the basis of familiar use of QQ working groups, YiBan groups, and education groups, continue to vigorously promote voting, forwarding and QQ telephone functions, so that network ideological and political education is carried out all the time, achieve the comprehensive publicity of network ideological and political education, and ensure that ideological and political education messages benefit from the majority of teachers and students at the first time.

The network is a miniature society, which is impacted and influenced by bad information like the real society, which brings not only an opportunity but also a challenge to ideological and political education. It is the only way for the matrix construction of network ideological and political education in local colleges and universities to make correct use of network platforms 
and resources, give college students sufficient trust and correct guidance, strengthen the construction of mainstream culture in network positions, and build an efficient and pragmatic work team. With the gradual deepening of the theoretical study of network ideological and political education, the forms, methods and models of network ideological and political education in colleges and universities will continue to break through and innovate, which provides a strong theoretical and practical basis for the current network ideological and political work in colleges and universities.

\section{CONCLUSION}

There are still some problems in the network ideological and political education in most colleges and universities, such as the weak construction of the network ideological and political education position, the uneven quality of network information, and the network ideological and political education model can not meet the needs of social development. This is because the function of the self media of the network ideological and political education in Colleges and universities has not been brought into full play, the network public opinion is lack of effective supervision and positive guidance. After investigation and research, it is decided to give suggestions from the following five aspects: promoting the construction of positions and expanding the influence of network culture in Colleges and universities; Strengthen the construction of College Students' Association or network education; Strengthen the supply of services and enhance the attraction of network culture in Colleges and Universities; Strengthen Internet thinking and organically combine online and offline ideological and political education;
Strengthen the construction of network carrier and enrich the content and form of network ideological and political education.

\section{REFERENCES}

[1] Chen Yan, Cui Lanxi.New Development of College Students' Network Ideological and Political Education in the Times of Financial Media [J]. Journal of Jiamusi Vocational College,2021,37(03):125-127.

[2] $\mathrm{Pu}$ Qingping, Li Tingting.Challenges and coping strategies of network ideological and political education in the era dominated by algorithm [J]. Journal of College Counselors,2021,13(01):43-49.

[3] Geng Haiyang. Discourse Power of Ideological and Political Education in Universities under the Background of Network Education [J].Teaching and Educating (Higher Education Forum),2021(06):12-13.

[4] Guo Yating. Influence of We Media on Socialization of College Students' Ideological and Political Education and Countermeasures [J].Teaching and Educating (Higher Education Forum),2021(06):9-11.

[5] Fan Lijun. Research on Innovation of College Students' Network Ideological and Political Education [D]. Shandong University,2020.

[6] Li Weina. Research on the Orientation of Ideological and Political Education in the Internet Era [D]. Harbin University of Science and Technology,2019. 